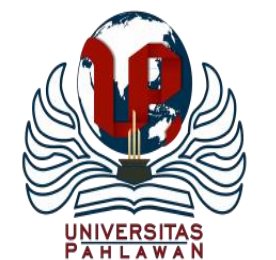

Jurnal Basicedu Volume 4 Nomor 3 Tahun 2020 Halm. 716 - 724

JURNAL BASICEDU

Research \& Learning in Elementary Education

https://jbasic.org/index.php/basicedu/index

\title{
Peningkatan Hasil Belajar Siswa Menggunakan Media Game Ular Tangga Digital
}

\author{
Lina Novita ${ }^{1}$, Fitri Siti Sundari ${ }^{2}$ \\ Program Studi PGSD, FKIP, Universitas Pakuan \\ E-mail : linovtaz@gmail.com ${ }^{1}$, fitri.siti.sundari@unpak.ac.id
}

\begin{abstract}
Abstrak
Keberhasilan suatu pembelajaran diantaranya dengan memanfaatkan media pembelajaran. Namun kenyataanya penggunaan media pembelajaran masih belum digunakan secara maksimal. Kondisi tersebut dapat disebabkan salah satunya dengan keterbatasan guru dalam pemahaman dan pengoperasian media berbasis teknologi. Oleh sebab itu perlu kiranya dibuat media yang dapat memfasilitasi pembelajaran. Penelitian ini dilakukan dengan tujuan meningkatkan hasil belajar menggunakan media ular tangga digital yang telah dibuat. Metode penelitian menggunakan Penelitian Tindakan Kelas (PTK). Siswa kelas IV berjumlah 35 orang dijadikan sebagai subjek dalam penelitian. Penelitian ini dilakukan dengan 2 siklus, terdiri dari perencanaan, pelaksanaan, pengamatan, dan refleksi. Perbaikan pembelajaran dilakukan pada siklus 2 apabila pada siklus 1 belum mencapai indikator keberhasilan pembelajaran. Pengumpulan dan analisis data dilakukan dari hasil pelaksanaan pembelajaran dan observasi yang dilakukan kolaborator. Hasil penelitian menunjukkan penggunaan media ular tangga digital dapat meningkatkan hasil belajar dan perubahan sikap pada materi pembelajaran I. Peningkatan dibuktikan dengan rata-rata pada siklus 1 , yaitu 74,42 dan meningkat menjadi 84,02 pada siklus 2 , artinya terjadi peningkatan 9,6. Dengan demikian disimpulkan bahwa media ular tangga digital dapat meningkatkan hasil belajar dan perubahan aktivitas siswa pada pembelajaran. Pembelajaran dengan menggunakan media baik itu ular tangga digital maupun media pembelajaran lainnya dapat mengubah pembelajaran menjadi lebih aktif.

Kata kunci: media ular tangga digital, hasil belajar
\end{abstract}

\begin{abstract}
The use of instructional media is increasingly felt important in motivating and attracting students' interests. This study was conducted with the aim of improving learning outcomes using digital ladder snake media that have been made. The research method uses Classroom Action Research (CAR). Class IV students totaling 35 people were used as subjects in the study. This research was conducted in 2 cycles, consisting of planning, implementation, observation, and reflection. Learning improvement is done in cycle 2 if in cycle 1 the indicators of learning success have not yet reached. Data collection and analysis is done from the results of the implementation of learning and observation by collaborators. The results showed that the use of digital ladder snake media could improve learning outcomes and change in the learning material I. The increase was evidenced by the average in cycle 1, which was 74.42 and increased to 84.02 in cycle 2, meaning an increase of 9.6. Thus it was concluded that the digital ladder snake media can improve learning outcomes and change student activities in learning. Learning by using media both digital snakes and other learning media can change learning to be more active.

Keywords: digital snake ladder media, learning outcomes
\end{abstract}

Copyright (c) 2020 Lina Novita, Fitri Siti Sundari

$\triangle$ Corresponding author :

Address : Perumahan Ambar Regency III Blok F2/8 Bogor $\quad$ ISSN 2580-3735 (Media Cetak)

Email : 1 linovtaz@gmail.com

Phone : 08567136219

ISSN 2580-1147 (Media Online)

DOI : $10.31004 /$ basicedu.v4i3.428 


\section{PENDAHULUAN}

Kurikulum 2013 memberikan ruang pada guru untuk terus berinovasi baik dalam pengembangan media maupun model pembelajaran. Pengembangan media dengan memanfaatkan teknologi merupakan salah satu inovasi yang perlu dilakukan guru. Namun kenyataannya, penggunaan media pembelajaran masih dirasa kurang maksimal digunakan. Guru masih menggunakan media yang tersedia di sekolah, tanpa berusaha dalam mengembangkan media tersebut. Kenyataan ini dapat disebabkan minimnya pengetahuan guru dalam konsep pengembangan dan penggunaan media terutama berbasis teknologi. Permasalahan ini diungkapkan dalam jurnal penelitian Sutisna, Novita \& Iskandar (2020), bahwa masih belum maksimalnya penggunaan media pembelajaran di sekolah dasar. Demikian juga dengan temuan hasil penelitian Novita, Windiyani, \& Fauziah (2020) tentang pemanfaatan media berbasis TIK yang masih rendah di lingkungan sekolah dasar. Merujuk permasalahan pada hasil observasi dan penelitian terdahulu, jelas bahwa pemanfaatan dan penggunaan media dalam pembelajaran perlu terus dikembangkan.

Penggunaan media dalam pembelajaran dikatakan penting, salah satunya dapat menjelaskan konsep yang abstrak pada siswa. Materi yang sulit dapat dijelaskan dengan bantuan media pembelajaran. Oleh sebab itu perlu kiranya ada terobosan dalam pembuatan media berbasis teknologi, yang nantinya dapat digunakan guru dalam mempermudah pembelajaran. Diperlukan kreativitas guru dalam membuat, mengembangkan dan menggunakan media dalam pembelajaran. Hasil wawancara dengan beberapa guru ditemukan bahwa guru masih mengajar tanpa menggunakan media pembelajaran. Dampak dari kurangnya penggunaan media salah sagtunya siswa menjadi kurang aktif dan kurang termotivasi dalam pembelajaran. Alternatif untuk mengatasi permasalahan tersebut, salah satunya dengan penggunaan media pembelajaran.

Penggunaan media pembelajaran telah banyak dijadikan objek dalam penelitian. Diantaranya penelitian dengan media pembelajaran ular tangga telah menarik perhatian Wulandari \& Munawar (2017) bahwa terdapat penagruh penggunaan ular tangga dalam kemampuan mengenal lambang bilangan. Kemudian penelitian Afandi (2015) yang mengembangkan media pembelajaran permainan ular tangga dalam pembelajaran Ilmu Pengetahuan Sosial (IPS) di sekolah dasar. Pentingnya media berbasis digital juga diteliti oleh Efendi (2018) yang mendeskripsikan penggunaan animasi digital sebagai metode pembelajaran siswa belajar aktif dalam revolusi pembelajaran berbasis digital.

Penelitian terdahulu di atas menarik peneliti untuk melakukan penelitian lanjutan di SDN Pengadilan 2 Kota Bogor. Penelitian yang akan dilakukan ini memilliki urgensi pada peningkatan hasil belajar terutama pada pembelajaran kurikulum 2013 yang lebih menekankan pada penguasaan materi dengan tema pada setiap muatan pelajaran. Dalam hal ini materi pada muatan pelajaran terkesan abstrak dan memiliki konten yang kurang. Dengan kondisi demikian maka penelitian perlu dilakukan agar pembelajaran di dalam kelas menjadi lebih bermakna, menyenangkan dan mengaktifkan siswa. Dengan berbantuan media pembelajaran, peserta didik akan lebih memiliki minat untuk belajar.

Penggunaan media ular tangga digital ini bertujuan untuk meningkatkan hasil belajar serta menemukan konsep-konsep baru terkait dengan materi pelajaran, terutama pada pembelajaran I keberagaman suku bangsa dan agama. Selain itu dengan penggunaan media berbasis digital ini 
motivasi dan minat siswa akan lebih berkembang, sehingga siswa lebih aktif dan kreatif. Dengan demikian hasil belajar pun akan meningkat.

$$
\text { Berbicara mengenai hasil belajar }
$$

dikemukakan Maisaroh, (2010:162) bahwa hasil belajar adalah hasil yang diperoleh seseorang dalam proses kegiatan belajar mengajar, dan hasil belajar tersebut dapat berbentuk kognitif, afektif dan psikomotorik yang penilaiannya melalui tes. Kemudian konsep hasil belajar juga dikemukakan Konsep hasil belajar dikemukakan Rusman (2015: 67) bahwa hasil belajar adalah sejumlah pengalaman yang diperoleh siswa yang mencakup ranah kognitif, afektif dan psikomotorik. Belajar tidak hanya penguasaan konsep teori mata pelajaran saja, tetapi juga penguasaan kebiasaan, persepsi, kesenangan, minat-bakat, penyesuaian sosial, macam-macam keterampilan, cita-cita, keinginan dan harapan. Hasil belajar dipengaruhi oleh beberapa faktor seperti yang dikemukakan oleh Ruhimat (2011:140) yang secara umum hasil belajar siswa dipengaruhi oleh faktor internal, yaitu faktor-faktor yang ada dalam diri siswa dan faktor eksternal, yaitu faktor-faktor yang berada di luar diri siswa.

Dapat disimpulkan bahwa hasil belajar merupakan suatu perolehan yang siswa baik sikap, pengetahuan dan keterampilan berdasarkan pengalaman belajar. Oleh sebab itu perlu adanya inovasi dalam pembelajaran agar kualitas hasil belajar semakin baik.

Perolehan hasil belajar akan baik, jika didukung salah satunya dengan penggunaan media pembelajaran. Gagne dalam Sadiman, dkk., (2014:6) berpendapat bahwa media merupakan salah satu komponen komunikasi ke komunikan. Media merupakan berbagai jenis komponen dalam lingkungan siswa yang dapat merangsangnya untuk belajar sehingga pembelajaran menjadi lebih bermakna. Adapun manfaat media pembelajaran menurut Sanjaya (2012:70) yaitu: 1) menangkap suatu objek atau peristiwa-peristiwa tertentu; 2) memanipulasi keadaan, peristiwa atau keadaan tertentu; 3) menambah gairah dan motivasi belajar siswa.

Dari pendapat-pendapat di atas, dapat disintesiskan bahwa media pembelajaran berbasis teknologi, informasi, dan komunikasi merupakan media atau alat yang sangat membantu pendidik dalam menyampaikan materi yang sulit disampaikan dan sulit dipahami oleh peserta didik, keunggulan dari media berbasis TIK ini yaitu dapat memeberikan pengalaman bagi peserta didik dalam proses pembelajaran yang abstrak atau sulit untuk dapat dipelajari dan diketahui dengan tepat.

Mengingat akan pentingnya penelitian ini, maka pelaksanaan penelitian dilakukan dengan tahapan perencanaan, pelaksanaan, observasi dan refleksi. Tahapan tersebut diawali dengan telaah kurikulum, buku guru dan juga buku siswa terkait dengan tema dalam penelitian. Kemudian disusun Rencana Pelaksanaan Pembelajaran (RPP) dengan penggunaan media ular tangga. Penelitian dapat terlaksana dengan harapan akan meningkatkan hasil belajar.

\section{METODE}

Pelaksanan penelitian bertempat di SD Negeri Pengadilan 2 Kota Bogor. Subjek penelitian dilakukan pada siswa kelas IV. Prapenelitian diawali bulan Maret 2020, menggunakan media whatsapp. Kemudian penelitian dilaksanakan pada bulan April 2020 dengan menggunakan kelas virtual, yaitu google classroom dan google meeting. Penelitian ini dilakukan dengan dua siklus, melalui rancangan penelitian sebagai berikut:

1. Prapenelitian, untuk mengetahui permasalahan yang nantinya dapat dijadikan penelitian. Bertujuan untuk memperbaiki 
719 Peningkatan Hasil Belajar Siswa Menggunakan Media Game Ular Tangga Digital - Lina Novita, Fitri Siti Sundari

DOI: 10.31004/basicedu.v4i3.428

dan meningkatkan pembelajaran.

Keragaman Suku Bangsa dan Agama di

2. Menganalisis data obyektif sekolah, terutama data kegiatan pembelajaran di kelas sekaligus menemukan masalah nyata yang akan segera dipecahkan melalui tindakan reflektif.

3. Menyusun rencana pelaksanaan pembelajaran (RPP) sesuai dengan kurikulum yang berlaku (K-2013); menyusun bahan ajar sesuai dengan kurikulum yang berlaku (K-2013); menyusun lembar kegiatan peserta didik (LKPD); menyusun lembar observasi dan rubrik penilaian; menyusun kisi-kisi dan instrumen tes (soal) aspek pengetahuan; menyusun lembar observasi dan rubrik penilaian aspek keterampilan.

4. Membuat media/alat pembelajaran, yang dalam hal ini media ular tangga digital, menyusun intsrumen penilaian perbaikan proses pembelajaran.

5. Melaksanakan pembelajaran sesuai dengan RPP dan melakukan penilaian hasil belajar, dengan menggunakan media ular tangga digital.

6. Teknik Pengumpulan data terdiri dari penilaian proses pelaksanaan pembelajaran dan penilaian autentik terdiri dari penilaian kompetensi sikap, observasi, pengamatan dengan menggunakan format yang berisi sejumlah indikator perilaku yang diamati, dan penilaian kompetensi pengetahuan, yaitu tes tertulis, soal-soal yang menghendaki siswa merumuskan jawabannya sendiri. Pengumpulan data mengenai hasil belajar berupa tes objektif yang sebelumnya diujicobakan untuk menguji validitas, reliabilitas, dan tingkat kesukaran butir soal, hasil belajar diukur dengan skor melalui posttest pembelajaran I

Negeriku.

7. Teknik analisis data menggunakan tabel konversi sebagai berikut:

Tabel 1 Konversi Nilai

\begin{tabular}{|c|c|c|}
\hline Konversi Nilai & Kategori & Interpretasi \\
\hline $81-100$ & $\mathrm{~A}$ & Sangat baik \\
\hline $61-80$ & $\mathrm{~B}$ & Baik \\
\hline $41-60$ & $\mathrm{C}$ & Cukup \\
\hline $21-40$ & $\mathrm{D}$ & Kurang baik \\
\hline Konversi Nilai & $\mathrm{E}$ & $\begin{array}{c}\text { Sangat kurang } \\
\text { baik }\end{array}$ \\
\hline
\end{tabular}

Penelitian ini menggunakan desain yang dikembangkan Kurt Lewin, sebagai berikut.

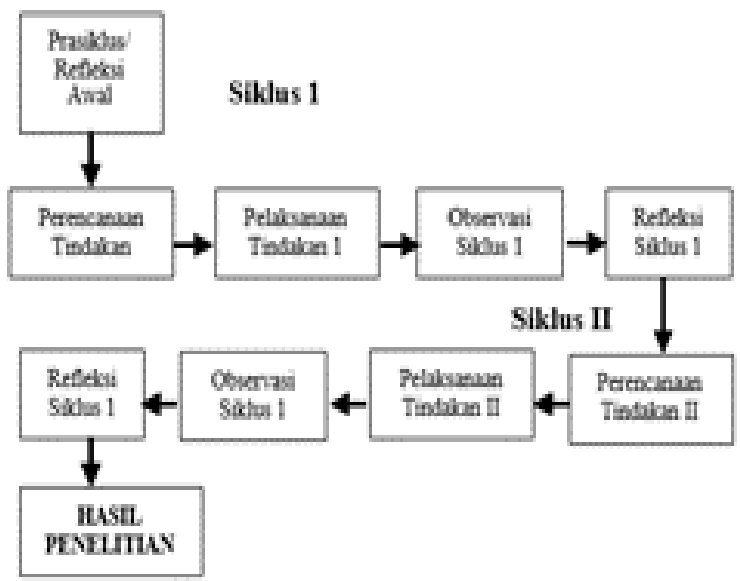

Gambar 1 Desain Penelitian Kurt Lewin

(Sugiyono, 2018:43)

\section{HASIL DAN PEMBAHASAN}

Data penelitian yang diambil berupa hasil evaluasi individu, hasil observasi guru dan observasi aktivitas siswa. Observasi aktivitas siswa dan guru dilakukan dengan google classroom dan google meeting. Observasi aktivitas siswa dan guru dilakukan dengan google classroom dan google meeting. Siklus I dilaksanakan pada tanggal $4 \mathrm{Mei}$ 2020. 
Pembelajaran dengan sistem baru ini menyebabkan guru, kolaborator dan siswa perlu penyesuaian pembelajaran. Oleh sebab itu pada siklus I, masih ada beberapa yang perlu diperbaiki. Hasil refleski siklus I, ditemukan bahwa guru masih belum sepenuhnya memberikan penjelasan terkait materi pelajaran. Kondisi tersebut dapat dipahami, karena pembelajaran bersifat online. Pembiasaan dalam pembelajaran online harus perlu dkitinkatkan lagi. Belum jelasnya persepsi yang disampaikan serta pemberian motivasi kepada siswa juga masih perlu diperbaiki. Temuan tersebut menjadi langkah awal perbaikan pada siklus II. Berikut rekapitulasi rata-rata hasil siklus I.

Tabel 2 Rekapitulasi Rata-rata Siklus 1

\begin{tabular}{|c|c|c|c|}
\hline $\begin{array}{l}\text { Proses } \\
\text { Pembelajar } \\
\text { an }\end{array}$ & $\begin{array}{l}\text { Perubahan } \\
\text { perilaku/ } \\
\text { aktivitas } \\
\text { siswa }\end{array}$ & $\begin{array}{l}\text { Ketuntasan } \\
\text { hasil } \\
\text { belajar }\end{array}$ & $\begin{array}{l}\text { Rata-rata } \\
\text { keseluruh } \\
\text { an siklus I }\end{array}$ \\
\hline 76,5 & 78,2 & 68,57 & 74,42 \\
\hline Baik & Baik & $\begin{array}{l}\text { Belum } \\
\text { Tuntas }\end{array}$ & Basik \\
\hline
\end{tabular}

Tabel 2 di atas, memberikan informasi bahwa ketika aspek yang diteliti masih perlu diperbaiki. Terutama pada ketuntasan hasil belajar yang merupakan aspek penelitian. Penyebab dari belum adanya peningkatan tersebut, diantaranya kesiapan guru dalam pembelajaran online. Guru, siswa, dan kolaborator masih merasa canggung dalam pembelajaran. Guru belum sepenuhnya menyesuaikan diri dalam pembelajaran, penyampaian apersepsi, penjelasan materi, seta motivasi untuk siswa belum tersampaikan dengan maksimal. Semua penyebab tersebut disampaikan pada saat refleksi. Oleh sebab itu dari hasil refleksi disimpulkan perlu adanya perbaikan siklus berikutnya, yaitu siklus II.

Pelaksanaan penelitian siklus II, dilakukan pada hari Kamis tanggal 12 Mei 2020, melalui google classroom dan google meeting. Adapun data yang didapat dari pelaksanaan Siklus II, yaitu sebagai berikut.

Tabel 3 Rekapitulasi Rata-rata Siklus II

\begin{tabular}{|c|l|l|l|}
\hline $\begin{array}{l}\text { Proses } \\
\text { Pembelajar } \\
\text { an }\end{array}$ & $\begin{array}{l}\text { Perubahan } \\
\text { perilaku/ } \\
\text { aktivitas } \\
\text { siswa }\end{array}$ & $\begin{array}{l}\text { Ketuntasan } \\
\text { hasil } \\
\text { belajar }\end{array}$ & $\begin{array}{l}\text { Rata-rata } \\
\text { keseluruh } \\
\text { an siklus } \\
\text { II }\end{array}$ \\
\hline 82 & 81,5 & 88,57 & 84,02 \\
\hline \multicolumn{3}{|c|}{ Sangat Baik } \\
\hline
\end{tabular}

Data tabel 3 menjelaskan bahwa terdapat peningkatan yang signifikan pada siklus II ini. Ketiga aspek mendapatkan peningkatan, dengan demikian penelitian selsai pada siklus II. Namun demikian penggunaan media pembelajaran harus tetap ditingkatkan dan dikembangkan lagi. Mengingat perkembangan teknologi yang semakin pesat, maka pembelajaran pun akan mengikuti platform 4.0, yaitu ke arah digitalisasi.

Berikut rekapitulasi data siklus I dan II yang terangkkum dalam tabel di bawah ini.

Tabel 4 Rekapitulasi Hasil Siklus I dan II

\begin{tabular}{|c|l|c|c|c|c|c|}
\hline \multirow{2}{*}{ No } & \multirow{2}{*}{ Aspek } & \multicolumn{4}{|c|}{ Hasil Siklus } & \multirow{2}{*}{ Ket. } \\
\cline { 3 - 6 } & & \multicolumn{2}{|c|}{ Siklus I } & \multicolumn{2}{c|}{ Siklus II } & \\
\cline { 2 - 6 } 1 & Nilai & Makna & Nilai & Makna & \\
\hline & $\begin{array}{l}\text { Proses } \\
\text { pembelaja } \\
\text { ran }\end{array}$ & $78,2 \%$ & Baik & $82,0 \%$ & $\begin{array}{c}\text { Sangat } \\
\text { Baik }\end{array}$ & $\begin{array}{c}\text { Meningkat } \\
3,8 \%\end{array}$ \\
\hline 2 & $\begin{array}{l}\text { Perubahan } \\
\text { perilaku } \\
\text { laktivitas } \\
\text { siswa }\end{array}$ & $76,5 \%$ & Cukup & $81,5 \%$ & Baik & $\begin{array}{c}\text { Meningkat } \\
5 \%\end{array}$ \\
\hline 3 & $\begin{array}{l}\text { Ketuntasa } \\
\text { n hasil } \\
\text { pembelaja } \\
\text { ran }\end{array}$ & 68,57 & Belum & 88,57 & Berhasil & $\begin{array}{c}\text { Meningkat } \\
20 \%\end{array}$ \\
\hline 4 & $\begin{array}{l}\text { Nilai rata- } \\
\text { rata hasil } \\
\text { belajar }\end{array}$ & 74,42 & $\begin{array}{l}\text { Belum } \\
\text { tuntas }\end{array}$ & 84,02 & Tuntas & $\begin{array}{c}\text { Meningkat } \\
9,6\end{array}$ \\
\hline
\end{tabular}

Tabel 4 menunjukkan ketiga aspek yang diteliti mengalami peningkatan. Pada siklus I pelaksanaan pembelajaran mencapai nilai 78,2\% dengan kategori baik, kemudian terjadi perbaikan pada siklus II dan meningkat menjadi $82,0 \%$ dengan kategori sangat baik. Begitu juga dengan perubahan perilaku siswa meningkat pada siklus II. 
Pada siklus I perubahan perilaku/aktivitas siswa mencapai nilai 78,2\% dengan interpretasi cukup baik, dan setelah dilakukan perbaikan pada siklus II maka nilai perubahan perilaku siswa meningkat menjadi $81,5 \%$ dengan interpretasi baik.

Aspek penelitian yang merupakan fokus penelitian, yaitu hasil belajar. Pada siklus I ketuntasan hasil belajar siswa kelas IV Sekolah Dasar Negeri Pengadilan 2 kota Bogor, secara klasikal hanya mencapai $68,57 \%$ kemudian mengalami peningkatan $20 \%$ pada siklus II menjadi $88,57 \%$, maka penelitian selesai dilaksanakan pada siklus II karena penelitian sudah mencapai indikator keberhasilan, yaitu 75 , yang artinya penelitian dengan penggunaan media ular tangga digital dikatakan berhasil. Rekapitulasi hasil penelitian siklus I dan II dapat digambarkan pada histogram di bawah ini.

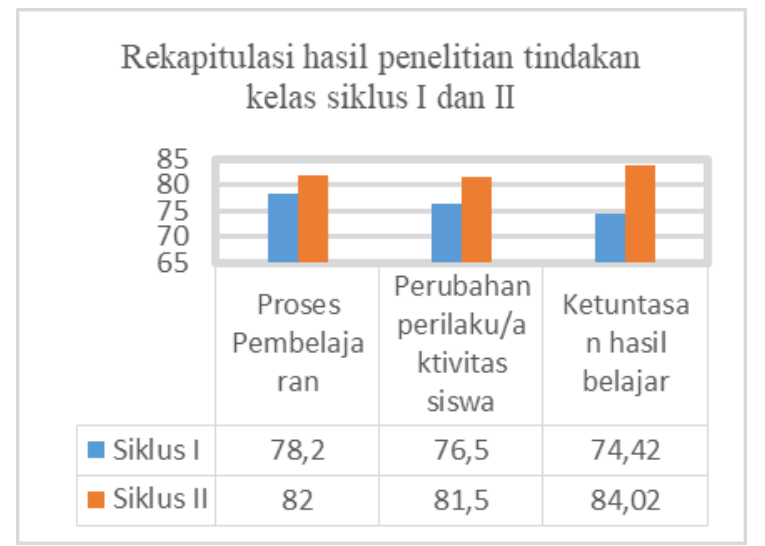

Gambar 2 Histogram Rekapitulasi Hasil Penelitian

Siklus I dan II

Penelitian tindakan yang telah dilaksanakan dapat diuraikan sebagai berikut.

1. Peningkatan proses pembelajaran

Hasil observasi yang dilakukan oleh kolaborator pada siklus I menunjukkan pembelajaran yang sudah baik. Namun pembelajaran dengan sistem online, menyebabkan masih perlu penyesuaian dengan sistem online. Rata-rata nilai diperoleh sebesar 78,2\%. Hasil tersebut dipengaruhi oleh beberapa kegiatan pembelajaran yang belum terlaksana dengan baik, seperti peneliti belum melakukan beberapa kegiatan seperti peneliti tidak memberikan motivasi dan mematangkan pengetahuan awal siswa pada kegiatan awal pembelajaran, guru masih belum terbiasa melakukan pembelajaran online, sehingga alokasi waktu menjadi tidak sesuai, penyampaian materi ajar belum sesuai dengan tujuan dan tidak tersampaikan dengan baik, perlu membiasakan diri untuk membagi perhatian antara siswa yang sedang presentasi dan siswa yang tidak presentasi.

Pengamatan kolaborator/observer pada siklus II mengalami peningkatan sebesar $82 \%$. Hal tersebut disebabkan guru sudah terbiasa dalam pembelajaran online. Guru juga sudah merasa nyaman dengan pembelajaran menggunakan google classroom dan google meeting.

2. Perubahan perilaku/aktivitas siswa

Perubahan perilaku atau aktivitas siswa didapat dari diskusi kelompok. Hal ini dilakukan untuk mengetahui aktivitas siswa dalam kelompok. Perubahan perilaku atau aktivitas siswa pada siklus I, memperoleh rata-rata nilai $76,5 \%$. Angka tersebut dapat diinterpretasikan baik, namun masih perlu ditingkatkan lagi keaktifan siswa dalam pembelajaran online ini. Pada siklus II terjadi peningkatan menjadi $81,5 \%$. Artinya siswa sudah terbiasa dengan pembelajaran online menggunakan google classroom dan google meeting.

3. Ketuntasan hasil belajar

Indikator keberhasilan hasil belajar minimal mencapai $75 \%$ dari jumlah siswa yang 
mencapai kriteria ketuntasan (KKM).

Ketuntasan hasil belajar pada siklus I mencapai angka 74,42. Nilai atau hasil siklus I yang artinya belum mencapai indikator keberhasilan, sehingga perlu dilakukan siklus II. Dengan memperbaiki proses pelaksanaan pembelajaran berdasarkan refleksi yang tetap mengacu pada penggunaan media ular tangga digital, maka pada siklus II terjadi peningkatan sebesar 84,02 . Artinya bahwa nilai tersebut sudah mencapai indikator keberhasilan, sehingga penelitian dapat dinyatakan berhasil.

Pembelajaran dapat dikatakan berhasil tidak terlepas dari peran guru dalam pelaksanaan pembelajaran dan faktor siswa itu sendiri. Penelitian dengan penggunaan ular tangga digital menunjukkan adanya peningkatan hasil belajar. Hal ini diperkuat oleh jurnal penelitian Novita, Sukmanasa, \& Pratama (2019), menemukan hasil penelitian adanya peningkatan hasil belajar dengan penggunaan media video.

Penelitian ini memiliki fokus pada media video, namun pada dasarnya memiliki kesamaan terkait dengan penggunaan media pembelajaran. Kemudian Widowati (2014) menemukan hasil penelitian yang menunjukkan adanya peningkatan hasil belajar dengan menggunakan media ular tangga berbasis teknologi. Kemudian Napitupulu \& Hardianti (2018), menemukan hasil penelitian bahwa penggunaan media ulara tangga berbasis macromedia flas berpengaruh pada hasil belajar siswa. Selanjutnya Nuryanti (2017) Haryanto \& Adiwiharja (2015) menemukan hasil penelitian bahwa media pembelajaran ular tangga yang disisipkan edukasi menjadi salah satu media yang dapat memudahkan siswa dalam memahami pelajaran yang diberikan oleh pengajar agar pembelajaran berjalan efektif yang menyenangkan serta menarik. Begitu juga Guterres, Sudarti, M, \& Putra (2018), dengan subjek penelitian siswa SMA dan metode penelitian yang digunakan kuasi, menemukan bahwa terjadi peningkatan hasil belajar dengan menggunakan media ular tangga berbasis android.

Merujuk dari data hasil penelitian dan penelitian relevan, dapat dikatakan bahwa media ular tangga dapat meningkatkan hasil belajar serta memotivasi siswa untuk aktif dalam pembelajaran. Penelitian-penelitian sebelumnya menunjukkan bahwa media pembelajaran sudah selayaknya digunakan dalam pembelajaran. Penggunaan media pembelajaran perlu terus dikembangkan baik itu yang berbasis teknologi maupun produk baru dalam upaya menciptakan kualitas pembelajaran yang lebih baik.

\section{SIMPULAN}

Penggunaan media pembelajaran ular tangga digital dapat meningkatkan hasil belajar subtema Bersyukur atas keberagaman kelas IV SDN Pengadilan 2 Kota Bogor. Hal ini dapat dilihat dari hasil penelitian mengenai, proses pembelajaran, perubahan perilaku siswa, dan hasil belajar.

Penggunaan media pembelajaran ular tangga digital mampu menciptakan suasana belajar yang menyenangkan dan tidak membosankan hal ini akan memicu semangat belajar dan motivasi belajar siswa, yang artinya bahwa penggunaan media pembelajaran ular tangga digital dapat meningkatkan hasil belajar, menumbuhkan motivasi serta minat belajar siswa kelas IV SDN Pengadilan 2 Kota Bogor.

Oleh sebab itu perlu kiranya dalam setiap pembelajaran digunakan media yang tepat. Hal tersebut bertujuan agar pembelajarn menjadi lebih bermakna dan kualitas hasil belajar semakin baik sesuai dengan tujuan yang ingin dicapai. Guru diharapkan dapat berinovasi menciptakan, 
membuat, serta mengembangkannya. Pesatnya kemajuan teknologi bukanlah suatu keniscayaan berinovasi dalam pembelajaran yang berbasis teknologi digital. Dengan demikian siswa yang aktif dan memeiliki kreativitas akan dapat terwujud sebagai tujuan dari pendidikan.

\section{DAFTAR PUSTAKA}

Efendi, Neng Marlina. 2018. Revolusi Pembelajaran Berbasis Digital (Penggunaananimasi Digital pada Start Up Sebagai Metode Pembelajaran Siswa Belajar Aktif). Habitus: Jurnal Pendidikan, Sosiologi dan Antropologi 2 (2):173-182, (https://jurnal.uns.ac.id/habitus/article/view File/28788/19628), diakses 26 April 2020.

Guterres, I. K. N. P., Sudarti, S., M, M., \& Putra, P. D. A. (2018). Pengembangan Media Pembelajaran Ular Tangga Berbasis Android Pada Pokok Bahasan Gejala Pemanasan Global Untuk Pembelajaran Fisika Di Sma. Jurnal Pembelajaran Fisika, $7(1)$, 54 https://doi.org/10.19184/jpf.v7i1.7225

Haryanto, F. D., \& Adiwiharja, C. (2015). Media Pembelajaran dengan Menggunakan Permainan Ular Tangga Berbasis Web. Jurnal Teknik Komputer. 1 (2): 266-274 (https://ejournal.bsi.ac.id/ejurnal/index.php/ jtk/article/view/260) diakses 20 April 2020.

Napitupulu, S. M., \& Hardianti, T. 2018. Penggunaan Media Ular Tangga Berbasis Macromedia Flash Pada Materi Glb Dan Glbb Terhadap Hasil Belajar Siswa Di Sma Al-Washliyah Medan Use of Ladder Snake Media Based on Macromedia Flash in Glb and Glbb Materials on Results Learning. 02, 9-14.

Novita, L., Sukmanasa, E., \& Pratama, M. Y. 2019. IPenggunaan Media Pembelajaran Video terhadap Hasil Belajar Siswa SD. Journal Indonesian Journal of Primary Education. 3 (2): 64-72, (https://ejournal.upi.edu/index.php/IJPE/artic le/view/22103) diakses 12 April 2020.
Novita, L., Windiyani, T., \& Fauziah, S. S. 2020. Analisis Pemanfaatan Media Pembelajaran Berbasis TIK di Sekolah Dasar Negeri Pengadilan 5 Kota Bogor. JPI (Jurnal Pendidikan Indonesia): Jurnal Ilmiah Pendidikan. 6 (1): 2443-3268, (https://jurnal.uns.ac.id/jpi/issue/view/2985), diakses 13 April 2020.

Nuryanti, E. (2017). Pengembangan Permainan Ular Tangga , Media Pembelajaran Jurnal Khusus Untuk Meningkatkan Development of Snake and Ladder Game , a Learning Media in. 45, 1-20.

Ruhimat, Toto. 2011. Kurikulum \& Pembelajaran. Jakarta: PT Rajagrafindo Persada.

Rusman. 2015. Pembelajaran Tematik Terpadu. Jakarta: PT Rajagrafindo Persada.

Sadiman, S. Arif, R.Rahardjo, dan Anung Haryono. 2014. Media Pendidikan Pengertian, Pengembangan, dan Pemanfaatannya. Jakarta: Pustekkom Dikbud dan PT Raja Grafindo Persada.

Sanjaya, Wina. 2012. Media Komunikasi Pembelajaran. Jakarta: Kencana Prenadamedia Group

Sugiyono. 2017. Metodologi Penelitian Kuantitatif, Kualitatif, dan R\&D. Bandung: Alfabedta.

Sutisna, Novita, I. (2020). Penggunaan Media Pembelajaran Berbasis Teknologi, Informasi, dan Komunikasi dalam Meningkatkan Hasil Belajar Subtema Lingkungan Tempat Tinggalku. Jurnal Pedagonal, Jurnal Ilmiah Pendidikan. 4 (1): 01-06.

(https://journal.unpak.ac.id/index.php/pedag onal/article/view/1929), diakses 13 April 2020

Widowati, F. 2014. Penggunaan Media Ular Tangga untuk Meningkatkan Hasil Belajar Siswa pada Tema Hiburan. Jurnal Penelitian Pendidikan Guru Sekolah Dasar. (1): 1-10, (https://jurnalmahasiswa.unesa.ac.id/index.ph p/jurnal-penelitian-), diakses 10 Mei 2019. 
724 Peningkatan Hasil Belajar Siswa Menggunakan Media Game Ular Tangga Digital - Lina Novita, Fitri Siti Sundari

DOI: $10.31004 /$ basicedu.v4i3.428

Wulandari, Kurnia Dewi dan Munawar, Muniroh. 2017. Pengaruh Media Permainan Ular Tangga Terhadap Kemampuan Mengenal Lambang Bilangan 1-10 pada Kelompok A di Ra As-Syuhada' Pedurungan Semarang Tahun Ajaran 2016/2017. PAUDIA. Jurnal Penelitian dalam Bidang Pendidikan Anak Usia Dini. 6(1): 25-34 http://journal.upgris.ac.id/index.php/paudia/ article/view/1863. Diakses 26 Mei 2020. 